\title{
Láthatatlan fordítás?
}

\section{A tudományos szakfordítás empirikus kutatásának eredményeiről funkcionális megközelítésben}

\author{
Károly Krisztina \\ E-mail: karoly.krisztina@btk.elte.hu
}

\begin{abstract}
Kivonat: A globalizációnak és korunk gyors technikai fejlődésének köszönhetően a tudományos világban a szakfordítói tevékenység ma minden eddiginél nagyobb méreteket ölt és komoly kihívásokkal küzd. A fordított tudományos szövegeknek ugyanis az eredetileg a célnyelven (többnyire angolul) született szövegekkel kell egyenértékủeknek lenniük ahhoz, hogy a bennük közölt ismeretanyag és tudás hiteles és versenyképes legyen. Elméleti és empirikus kutatások százai foglalkoznak a tudomány fordításának koncepcionális, diszciplináris, gyakorlati, módszertani, kulturális, stratégiai, vagy éppen politikai kérdéseivel. Arra keresnek választ, hogy melyek azok a tulajdonságok, feltételek, amelyek révén a fordítások ekvivalenssé válhatnak az eredetileg az adott nyelven (anyanyelvüek által) írt szövegekkel. Dolgozatom a tudományos szakfordítás empirikus kutatásának eredményeit tekinti át azzal a szándékkal, hogy azonosítsa ennek a speciális fordítói tevékenységnek (1) a sajátos kihívásait, (2) az ezek leküzdéséhez szükséges kompetenciákat, valamint (3) azokat a szövegalkotási normákat és minőségi kritériumokat, amelyek révén az anyanyelvủek által írt szövegekkel funkcionálisan egyenértékủ célnyelvi szöveg keletkezhet, vagyis „láthatatlanná” válhat a fordítás. A kutatási eredményeket a szakfordítást leginkább befolyásoló tényezők figyelembevételével a különféle nyelvpárok, müfajok és tudományterületek vonatkozásában mutatom be.
\end{abstract}

Kulcsszavak: tudományos szakfordítás, egyenértéküség, diszciplína, nyelvpár, müfaj, funkcionális megközelítés

\section{Bevezetés}

A tudományos élet szereplői az emberiség története során mindent elkövettek annak érdekében, hogy új ismeretek birtokába jussanak és megszerzett tudásukat minél szélesebb körben megosszák. Ehhez mindig is egy olyan közös nyelvre volt szükségük, amelyet mindannyian megértettek, még akkor is, ha térben és időben

Hivatkozás: Károly K. 2021. Láthatatlan fordítás? A tudományos szakfordítás empirikus kutatásának eredményeiről funkcionális megközelítésben. Forditástudomány 23. évf. 1. szám. 21-48. DOI: https://doi.org/10.35924/fordtud.23.1.2 
távol éltek egymástól. Ez a választott nyelv az idők során többször változott (korábban például a görög, az arab vagy a latin volt, ma az angol), de mindig jelentős szerepet töltött be a tudomány, a tudományos gondolkodás, s következésképp a tudományos diskurzus és kommunikáció alakulásában (erről bővebben ld.: Károly 2019, Montgomery 2000). A mindenkori tudományos lingua franca-n történő sikeres kommunikáció ezáltal a tudományos életben való eredményesség, versenyképesség, az ismertség és egyben az elismertség feltételévé is vált. Akinek ez a választott nyelv nem az anyanyelve volt, arra kényszerült, hogy fordítson vagy fordíttasson, annak érdekében, hogy más kultúrákban élő társaival megértesse magát.

Korunk rendkívül gyors technikai fejlödésének és a globalizációnak köszönhetően ez a (tudományos) fordítási tevékenység ma minden eddiginél nagyobb méreteket ölt, elsősorban az angolra és az angolról történő fordítás terén. Az így létrejövő (fordított) szövegeknek minden szempontból az eredetileg angol nyelven született szövegekkel kell egyenértéküeknek lenniük ahhoz, hogy a bennük közölt ismeretanyag és tudás hiteles és versenyképes legyen: a rangos nemzetközi fórumokon (szakfolyóiratokban, konferenciákon stb.) csak tartalmilag, formailag és nyelvileg magas színvonalú, az angol tudományos szövegnormáknak minden tekintetben megfelelő írások vagy előadások kapnak helyet. Tovább fokozza az angol nyelven történő sikeres nemzetközi kommunikáció jelentőségét az a tény is, hogy a szakmai/tudományos megmérettetés bármely területén (legyen szó kutatási pályázatról, munkahelyi előléptetésről vagy bármi másról) az elismert nemzetközi szakfolyóiratban vagy kiadónál megjelent müvek száma a világon szinte mindenhol az egyik legfontosabb mutató. Nem véletlenül írja Day és Gastel a tudományos publikálás mikéntjéről írt könyvében azt, hogy ma „a jó tudományos írás nem élet-halál kérdése, hanem sokkal komolyabb dolog annál”. (2006/2016: ix) ${ }^{1}$

Nem meglepő ezért, hogy a tudományos szakfordítás kutatása iránti igény is jelentősen megnövekedett az elmúlt évtizedekben. Elméleti és empirikus munkák százai foglalkoznak a tudomány fordításának koncepcionális, diszciplináris, gyakorlati, módszertani, kulturális, stratégiai, vagy éppen politikai kérdéseivel. A vizsgálatok mindenekelőtt arra a kérdésre keresnek választ, hogy melyek azok a tulajdonságok, feltételek, amelyek révén a fordítások ,egyenértéküvé” válhatnak, vagyis azonos funkciót tölthetnek be az eredetileg az adott nyelven (anyanyelvüek által) írt szövegekkel: melyek azok a tényezők, amelyektől úgyszólván „láthatatlan" a fordítás?

Dolgozatom a tudományos szakfordítás empirikus kutatásának eredményeit tekinti át azzal a szándékkal, hogy azonosítsa ennek a speciális fordítói tevékenységnek (1) a sajátos kihívásait, (2) az ezek leküzdéséhez szükséges kompetenciákat, valamint (3) azokat a szövegalkotási normákat és minőségi kritériumokat, amelyek révén az anyanyelvűek által írt szövegekkel funkcionálisan egyenértékü célnyelvi szöveg keletkezhet, vagyis láthatatlanná válhat a fordítás. A kutatási eredményeket a szakfordítást leginkább befolyásoló tényezők figyelembevételével elsőként a különféle nyelvpárok vonatkozásában, majd müfajok szerint (pl. szakfolyóirat-cikk, monográfia, tankönyv, absztrakt), végül diszciplináris bontásban tudományterüle- 
tenként - az orvostudományt, a gazdaságtudományt, a történelemtudományt, az irodalom- és kultúratudományt stb. külön-külön érintve - tárgyalom. Az áttekintés tehát céljából fakadóan szükségszerüen szelektív, és nem vállalkozik a témában született összes kutatási eredmény bemutatására. ${ }^{2}$

Mielőtt rátérek az eredmények áttekintésére, fontos tisztázni mit értek „funkcionálisan egyenértékü" fordításon. Funkcionális megközelítésben a fordítás során a célnyelvi szövegalkotásra kerül a hangsúly és arra, hogy a keletkezö szöveg megfeleljen a befogadók elvárásainak és a célnyelvi kultúra egyes szövegfajtákkal szemben támasztott követelményeinek (erről ld. még Neubert és Shreve 1992: 7, Vincze 2004: 29). Ehhez szorosan kapcsolódik a fordítás kommunikatív és pragmatikai szempontú megközelítése is (ld. Reiss és Vermeer 1984), melyben kiemelt szerephez jutnak a kommunikáció kultúra- és helyzet-specifikus vonatkozásai: a fordító feladatának, felelösségének tekintik azt, hogy olyan célnyelvi szöveget hozzon létre, amely képes betölteni kommunikációs célját. A fordításoknak tehát autonóm, önálló szövegként kell müködniük, és nem mutathatják jelét annak, hogy fordítás nyomán keletkeztek (Williams 2005: 124). De Beaugrande (1997: 370) felfogásában a fordítás funkcionális, kognitív és társadalmi diskurzuscselekedet. Következésképp, az eredeti/anyanyelvi szövegalkotáshoz hasonlóan „kommunikatív eseménynek” minősül (de Beaugrande 1997, Nord 1997: 2). Akkor képes tehát elérni a célját, ha az - Jakobsen (1993: 157) terminusaival élve - „funkcionális" és ,természetes” szöveg, vagyis olyan, mint az eredeti szövegek. Egy fordítás ily módon akkor tekinthető funkcionálisan egyenértékünek, ha az olyan, mint a célnyelven születő eredeti (anyanyelvi beszélők által írt) szövegek. A következőkben ezt a minőséget járom körül a vizsgált nyelvek, müfajok és tudományterületek perspektívájából.

\section{A nyelvpárokra irányuló vizsgálatok eredményei}

\subsection{A leginkább vizsgált nyelvek}

Ma a tudományos kommunikációban szerepet játszó műfajok (a szakfolyóirat-cikkek, konferencia előadások, monográfiák stb.), a nemzetközi együttmüködési hálózatok és kutatási projektek, valamint a külföldi diákok számára hirdetett oktatási programok (s az ezek keretében születő müfajok: kutatási tervek/jelentések, tankönyvek, dolgozatok stb.) lingua franca-ja az angol. Nem meglepö tehát, hogy a kutatások zöme az angolra, illetve az angolról valamilyen más nyelvre történő fordítást vizsgálja (pl. spanyol, portugál, brazíliai portugál, francia, kínai, japán, arab, perzsa, török, dán, holland, német, finn, magyar, lengyel, orosz, szlovén). Az angol és a spanyol nyelvpár vonatkozásában áll rendelkezésre a legtöbb kutatási eredmény, de születtek elemzések arab $\rightarrow$ spanyol, francia $\rightarrow$ arab, német $\rightarrow$ spanyol, orosz $\rightarrow$ finn és angol $\rightarrow$ magyar irányban is. A különféle nyelvpárokra irányuló vizsgálatokról az 1. táblázat nyújt összefoglaló áttekintést. Az alábbiakban azokat a munkákat tekintem át, amelyek egy nyelvpáron belül többféle müfajt is felölelnek. 


\section{1. táblázat \\ A különféle nyelvpárokra irányuló empirikus vizsgálatok}

\begin{tabular}{|l|l|}
\hline \multicolumn{1}{|c|}{ Nyelvek, nyelvpárok (szövegfajták) } & \multicolumn{1}{c|}{ Szerzö(k) } \\
\hline $\begin{array}{l}\text { angol, francia, német, spanyol, orosz (müszaki, } \\
\text { tudományos szöveg) }\end{array}$ & Aixelá (2004) \\
\hline angol-brazíliai portugál (konferencia-felhívás) & Tack Erten (2012) \\
\hline angol-kínai (természettudományos tankönyv) & Xiangtao (2007) \\
\hline angol-dán (orvostudományi cikk) & Pilegaard (1997) \\
\hline angol-dán (filozófiai szöveg) & $\begin{array}{l}\text { Vandepitte, Vandenbussche } \\
\text { és Algoet (2011) }\end{array}$ \\
\hline $\begin{array}{l}\text { angol-francia (tudományos írás, dokumentumfilm) } \\
\text { (filozófiai szöveg) }\end{array}$ & $\begin{array}{l}\text { Hoorickx-Raucq (2005) } \\
\text { Joken és Roorick (2011) }\end{array}$ \\
\hline angol-japán (mérnöki tudományos cikk) & Meade (2011) \\
\hline angol-perzsa (nötudományos szöveg) & Farahzad (2003) \\
\hline angol-lengyel (orvosi zárójelentés) & Pietrzak (2015) \\
\hline $\begin{array}{l}\text { angol-magyar (filozófiai szöveg) } \\
\text { (fordítástudományi szöveg) } \\
\text { (irodalmi és tudományos szakfordítás) } \\
\text { (betegtájékoztató) }\end{array}$ & $\begin{array}{l}\text { Albert (2000, 2001) } \\
\text { Götz (2015) } \\
\text { Heltai (2008) } \\
\text { Mány (2019) }\end{array}$ \\
\hline arab-spanyol (tudományos szöveg) & Gil-Bardají (2009) \\
\hline arab fordítás (orvostudományi cikk) & Sharkas (2011) \\
\hline $\begin{array}{l}\text { finn-angol (gazdasági szakszöveg) } \\
\text { (ösztöndíjpályázat) }\end{array}$ & $\begin{array}{l}\text { Mauranen (1993) } \\
\text { Tirkkonen-Condit (2001) }\end{array}$ \\
\hline francia-arab (társadalomtudományi szöveg) & Jacquemond (2015) \\
\hline francia-angol (tudományos szakfordító képzés) & Bowker (2016) \\
\hline galíciai-angol (környezettudományi cikk) & $\begin{array}{l}\text { Fernández-Silva és Ker- } \\
\text { remans (2011) }\end{array}$ \\
\hline német-angol (tudományos szakszöveg) & Watt (1993) \\
\hline német-spanyol (tudományos szerzödés) & Sánchez (2011) \\
\hline orosz-finn (politikatörténeti szöveg) & Kemppanen (2004) \\
\hline szlovén-angol (tudományos szakcikk) & $\begin{array}{l}\text { Pisanski Peterlin (2005, } \\
\text { 2008a, 2008b, 2014) }\end{array}$ \\
\hline török-angol (történelemkönyv) & Aksoy (2001) \\
\hline
\end{tabular}


Az angolról arabra történő fordítás területén monográfiák (Jawad 2014), tudományos könyvek és szövegek (Nasser 2014, Al-Hassnawi 2007), valamint szakfolyóirat-cikkek (Hamdan és Natour 2014) vizsgálatára került sor. Szintén jelentős mennyiségű kutatási eredmény áll rendelkezésre az angol-német fordításról: Gerzymisch-Arbogast (1993) közgazdasági tankönyvek, Stolze (2003) gazdasági szövegek fordítását elemezte, Krüger (2016) pedig kutatási jelentéseket és folyóiratcikkeket vizsgált. Bennett a portugálról angolra fordítás sajátosságait írta le az irodalom- és kultúratudomány területén (2006), és általánosabban a tudományos szakfordításban $(2008,2012)$, valamint a müszaki szakfordításban (2011).

Ahogy a korábbiakban is említettem, a legszélesebb körü kutatási tevékenység az angol-spanyol fordításokat jellemzi. Figyelemre méltó eredmények születtek a közgazdasági témájú kézikönyvekröl (Fuertes-Olivera és Pizarro-Sánchez 2002), a különféle orvostudományi szakszövegek fordításáról (pl. García Hidalgo és Dunham 1981, Muňoz-Miquel 2018, Jimenez-Crespo 2018, López-Arroyo és MéndezCendón 2007, Mendiluce-Cabrera és Bermúdez-Bausela 2006, Méndez-Cendón 2009, Williams 2004, 2005, 2007), a tudományos regiszter és múfajok célnyelvi megfeleltetésének kérdéseiről (López-Arroyo és Roberts 2017), valamint a mérnöki tudományok területén születő fordítások sajátosságairól (López-Rodríguez és Tercedor-Sánchez 2008).

A magyar nyelvre történő fordítással is többen foglalkoznak (pl. Albert 2000, 2001, Götz 2015, Heltai 2008, Mány 2019). Albert Sándor (2000, 2001) a filozófiai szövegek célnyelvi átültetésének kérdéseit tárgyalja Martin Heidegger Lét és idő címü, sokak által egyébként fordíthatatlannak tartott müvének magyar, francia, angol, olasz és spanyol fordításai alapján. Götz Andrea (angol $\rightarrow$ magyar) tudományos absztraktokat vizsgál műfaji szempontból, Heltai Pál (2008) pedig az irodalmi és a tudományos (angol $\rightarrow$ magyar) szakfordítás különbségeit és hasonlóságait tárja fel a lexikai átváltási művelet szempontjából. Mány Dániel (2019) az orvostudományi terminusokhoz köthető eufemizmusok angolról magyarra fordítását elemzi betegtájékoztatókban. Munkáját az motiválja, hogy az eufemizmusok nyelvenként és kultúránként jelentős eltéréseket mutatnak. Ezért a fordítónak szem elött kell tartania a szakmai szempontokat éppúgy, mint a (laikus) célnyelvi olvasó feldolgozási nehézségeit, pszichológiai teherbírását és a célnyelvi normákat.

\subsection{A nyelvek közötti különbségek okozta kihívások}

A kutatási eredmények arra engednek következtetni, hogy a funkcionális ekvivalencia megteremtése során a fordítók számára a legnagyobb kihívást a nyelvek rendszerbeli (Bennett 2011: 202), retorikai szerkezeti, müfaji és regiszterbeli eltéréseiből (Olohan és Salama-Carr 2011: 181-187), valamint a nyelvi interferenciából fakadó problémák kezelése okozza. Ilyen nehézségeket jelenthet például azon jelenségek sora, amelyeket Bennett (2011: 205) a hagyományos portugál diskurzusokban talált: a túlságosan hosszú mondatok (a korpuszában szereplő egyik orvosi szakszövegben az egyik mondat 322 szóból állt), a rendkívüli szintaktikai 
komplexitás, az ige nélküli mondatok, a klasszikus/humanista retorikai hagyományokban gyökerező trópusok és szóképek célnyelvi megfeleltetése. A portugálról angolra fordítás esetében ezek olyan fordítói stratégiák alkalmazását indukálják, mint például a szintaktikai egyszerüsítés, a verbalizáció, valamint a stiláris egyszerüsítés.

A fordítói tapasztalat és a fordítástudományi kutatások rávilágítanak még egy, szintén a nyelvek egyedi sajátosságaihoz köthető és a fordítási tevékenységet meghatározó tényezőre: a nyelvezet szakszerüségi és absztrakciós fokára. A kutatások és a gyakorló fordítók is egybehangzóan úgy vélik, hogy a különféle tudományterületeken és nyelveken/kultúrákban születő müvek nyelvezetének tudományos szakszerüségi szintje (absztrakciós képessége) nem egyenszilárdságú, hanem eltéréseket mutat. Albert Sándor (2000) munkájában olvashatunk például arról, hogy a filozófiai szövegek megértése (s következésképp a fordítása is) egyedülálló kihívásokat jelent az egyéb tudományterületekéhez képest. Ö írja le azt is, hogy ,a magyar filozófiai nyelvezet az absztrakciónak sokkal alacsonyabb fokán áll, mint a francia" (2000: 6). Baumgarten, House és Probst (2004: 104-105) pedig az angol és a német elemzése során állapította meg, hogy a német szövegek általában jóval tudományosabbak, precízebbek, szakszerübbek a megfogalmazásaikban, mint angol-amerikai megfelelőik. A különféle müfajokra és diszciplínákra jellemző konkrét fordítási problémákat és ezek megoldási lehetőségeit a következő két fejezet tárgyalja.

\section{A különféle tudományos müfajok fordítására irányuló kutatások}

A tudományos müfajok (az orvosi zárójelentés, kézikönyv, szakfolyóirat-cikk, absztrakt, konferencia-felhívás, tankönyv, szakkönyv/monográfia, esetleírás, ösztöndíjpályázat stb.) a kutatók és a szakemberek közötti kommunikáció eszközei nem csupán a kutatásban és a képzésben (pl. felsőoktatásban), hanem a természetés a társadalomtudományok elméleti és alkalmazott területein is. A területen végzett kutatások azonban nem mondhatók kiegyensúlyozottnak: egyes müfajokra jelentős kutatói figyelem összpontosul (ilyen pl. a szakfolyóirat-cikk vagy az absztrakt), míg mások iránt kisebb az érdeklődés (pl. konferencia-felhívás, esetleírás). Mindazonáltal a rendelkezésre álló eredmények alapján jól látható, hogy sokaságuk ellenére e müfajok számos hasonlóságot mutatnak, s következésképp hasonló kihívások elé is állítják a fordítót (nyelvpároktól függetlenül).

A különféle tudományos kutatási és oktatási müfajok fordításával foglalkozó munkák összefoglaló áttekintése a 2. táblázatban található. A kutatások zöme a szakfolyóirat-cikk műfajra és az orvostudományi szakterületre összpontosul. Ezért a következőkben elsősorban ezek bemutatására törekszem, és utána térek rá azokra a müfajokra, amelyek a szakcikkhez szorosan kapcsolódnak: az absztrakt, a konferencia-felhívás és a kutatási terv. 


\section{2. táblázat Müfaj-orientált kutatások}

\begin{tabular}{|c|c|}
\hline & A fordításkutatásban vizsgált műfajok (és a szerzők) \\
\hline $\begin{array}{l}\text { oktatási } \\
\text { müfajok }\end{array}$ & $\begin{aligned} \text { - } & \text { közgazdasági kézikönyv (Fuertes-Olivera és Pizarro-Sánchez 2002) } \\
\text { - } & \text { környezetismeret tankönyv (általános és középiskolások számára) } \\
& \text { (Xiangtao 2007) } \\
\text { - } & \text { történelem tankönyv (Aksoy 2001, Wright és Wright 1993) } \\
\text { - } & \text { tudományos multimédiás tananyag (Camara és Espasa 2011) } \\
\text { - } & \text { oklevélmelléklet és diploma (Mayoral 2003/2014) }\end{aligned}$ \\
\hline \multirow[t]{2}{*}{$\begin{array}{l}\text { tudományos } \\
\text { kutatási } \\
\text { múfajok }\end{array}$} & $\begin{aligned} \text { - } & \text { orvostudományi szakcikk (pl. Mendiluce-Cabrera és Bermúdez- } \\
& \text { Bausela 2006, Pilegaard 1997, Sharkas 2011, Williams 2004) } \\
\text { - } & \text { orvosbiológiai szakcikk (pl. Williams 2005, 2007) } \\
\text { - } & \text { földtudományi szakcikk (Pisanski Peterlin 2008a, 2008b) } \\
\text { - } & \text { orvostudományi absztrakt (López-Arroyo és Méndez-Cendón 2007) } \\
\text { - } & \text { fordítástudományi absztrakt (Götz 2015) } \\
\text { - } & \text { konferencia-felhívás (Tack Erten 2012) }\end{aligned}$ \\
\hline & - monográfia (Jawad 2014) \\
\hline $\begin{array}{l}\text { egyéb } \\
\text { múfajok }\end{array}$ & $\begin{array}{l}\text { - orvosi esetjelentés (Méndez-Cendón 2009) } \\
\text { - orvosi zárójelentés (Pietrzak 2015) } \\
\text { - betegtájékoztató (Mány 2019) } \\
\text { - ösztöndíjpályázat (kutatási terv) (Tirkkonen-Condit 2001) }\end{array}$ \\
\hline
\end{tabular}

\subsection{A tudományos szakfolyóirat-cikk fordítása}

Az orvostudományi cikkek fordításával kapcsolatos kihívásokról és a jellegzetes fordítási stratégiákról Pilegaard (1997) munkájában olvashatunk részletes áttekintést a spanyol, a francia és a német, valamint a dán, a holland és a kínai nyelv vonatkozásában. Kutatását az a korábbi tanulmányokban már többször leírt probléma motiválta, hogy miközben fordítási nehézségek minden létező szinten megjelennek, a fordítóknak nincs meg az az elméleti és gyakorlati eszköztára, aminek segítségével ezeket meg tudnák oldani. Pilegaard hierarchikus megközelítésben mutatja be az angol-dán fordítás során felmerülö problémákat: a legalacsonyabb szintről, a morfológiai és a szószintű ekvivalencia kérdéseitől indulva veszi végig a különféle szintaktikai, majd szövegszintü (a pragmatikai ekvivalenciához is kapcsolódó) nehézségeket. Elemzései alapján rámutat azokra a stratégiákra, amelyek az orvostudományi szakcikkek fordításában különösen kívánatosak. Ajánlásai a következőkben foglalhatók röviden össze: fordítás során célszerü

(1) minden nyelvi szinten ekvivalenciára törekedni (lexikai, szintaktikai és szövegszinten); 
(2) elvégezni az adott müfaj és kultúra szöveghagyományai/-normái által indukált lexikai, szintaktikai és pragmatikai módosításokat;

(3) a fordítónak és a szerzőnek szorosan együttmüködnie annak érdekében, hogy megtalálják a megfelelő egyensúlyt a (nemzetközi/angol) tudományos szakfolyóirat-cikk müfaji konvenciói, a folyóirat szerkesztői elvárásai és a szerző egyéni stílusa között.

Pilegaard (1997) ajánlásai olyan speciális fordítói stratégiákat foglalnak magukba, amelyeket egy korábbi munkámban „müfajtranszfer stratégiáknak” neveztem el:

A müfaj-transzfer stratégiák olyan - általában tudatos - fordítói döntések eredményeként alkalmazott eljárások, amelyek célja a forrásnyelvi szöveg müfaji identitásának megőrzése a célnyelvi fordításban. A terminus magába foglalja mindazokat a fordítói döntéseket, amelyeket a fordítók az ún. „funkcionális fordítás" (Nord, 1991, 1995; Reiss és Vermeer, 1984) érdekében hoznak, vagyis hogy kommunikatív és funkcionális értelemben ekvivalens célnyelvi szöveget hozzanak létre és a fordítás megfeleljen a célnyelvi szituációnak és szándéknak. A terminus ezért tartalmazza a „transzfer” fogalmát. Itt ugyanis - az eredeti szövegalkotással ellentétben - a forrásnyelvi szövegböl indul ki a fordító, és arra keres megoldást, hogy miként „,vigye át” a forrásnyelvi szöveg müfaji sajátságait a célnyelvi szövegbe. (Károly 2007: 213)

A tudományos szakfolyóirat-cikkek fordítása során e stratégiák hatékony alkalmazása (és az ehhez szükséges fordítói kompetenciák megléte) különleges jelentőségü.

Szintén az orvostudomány területén, Sharkas (2011) egy igen gyakori stratégiát vizsgált: a magyarázó jegyzetek beszúrását (amikor például idegen nyelvü szavakat illesztenek be a célnyelvi megfelelök mellé). Sharkas arabra fordított és eredeti arab orvosi szakcikkeket vetett össze, hogy feltárja az ilyen betoldások lehetséges okait (tekintettel az arab és az angol nyelv közötti rendszerbeli különbségekre és a mögöttük álló tudásbázis potenciális eltéréseire). Azt találta, hogy míg a forrásnyelvi szakterminusokat magyarázó betoldások a korpuszában mind a fordításokban, mind pedig az eredeti szövegekben fellelhetők voltak, ezek aránya az eredeti szövegekben alacsonyabb volt, mint a fordításokban. Az eltérést az eredeti szövegek megírása mögött rejlö történelmi, oktatási és nyelvi hagyományokra vezette vissza (2011: 369).

Jelentős kutatási tevékenység irányul az orvostudomány különféle területein a spanyol $\rightarrow$ angol szakfordításra. Érdekes módon a két nyelv találkozásában a legnagyobb kihívást nem a szakterminológia megfeleltetése okozza a fordítók számára, hanem sokkal inkább a retorikai szerkezet átültetése, konkrétan a szakcikkek szöveg- és érvelési struktúrájának újraalkotása a célnyelven (Mendiluce-Cabrera és Bermúdez-Bausela 2006: 447-448). Megnehezítheti a fordítók dolgát, hogy nem mindig egyértelmü az sem, hogy az angol fordításban a brit vagy az amerikai szöveghagyományokat kell követni (vagy éppen az angolnak valamelyik másik 
változatát). Mendiluce-Cabrera és Bermúdez-Bausela (2006) vizsgálatai ezért erre a problémára összpontosulnak. Arra mutatnak rá, hogy a globalizáció terjedésével, különösen az 1950-es évektől kezdődően - és elsősorban nem nyelvi okokból -, a nemzetközi tudományos diskurzusban egy speciális, kompromisszumos angol kezdett kifejlödni az anyanyelvi és nem anyanyelvi beszélök között. Azóta már az anyanyelvi beszélők is elismerik, hogy létezik egy olyan, a nem anyanyelvüek által beszélt ún. „nemzetközi angol”, amelynek már legitim kommunikációs státusza van (2006: 449). Mendiluce-Cabrera és Bermúdez-Bausela (2006: 453) áttekinti a tanulmányuk megjelenése előtti 25 évben azokat a sokszor egyáltalán nem természetes kísérleteket is, amik a tudományos angol mint lingua franca speciális szabályrendszerét meg akarták határozni (ilyen volt pl. az ún. BASIC English, a Nuclear English, vagy a Controlled English). Korunk lingua franca-ja tehát nem egyszerüen az angol, hanem a nemzetközi angol (angolul: International English röviden: $I E)^{3}$. Mendiluce-Cabrera és Bermúdez-Bausela szerint az orvostudomány kulturálisan igen heterogén nemzetközi szereplői közötti kommunikációhoz kifejlődött még egy ún. „orvosi nemzetközi angol” is, ami már egy olyan nyelvváltozat, ami csupán a nemzetközi orvostudományi szakfolyóiratokban létezik. Arról számolnak be, hogy ehhez hasonló módon, csak éppen spanyolul, gazdasági érdekekből, a szoftverek fordítása nyomán is kialakult egy ún. „semleges spanyol” (angolul: neutral Spanish) nyelv, ami pedig csak a spanyol számítógépeken, PC-ken létezik (2006: 453).

Ez azonban nem az egyedüli munka, ami a retorikai/szövegszerkezeti transzfer jelenségével foglalkozik. Williams $(2004,2005)$ orvostudományi szakcikkek módszerekről (Methods) és eredményekről (Discussion) szóló fejezetének angolról spanyolra történő fordítását vizsgálta, célnyelvre orientált, összehasonlító elemzéssel. Célja olyan korrekciós stratégiák azonosítása volt, amik segítségével elkerülhetö, hogy természetellenes hangzású szöveg keletkezzen. A módszertani fejezetekben (Methods) a téma-réma szerkezetet, valamint a személyekre mint klinikai vizsgálati alanyokra utaló lexikai elemeket vizsgálta (Williams 2004). Korpuszában számos statisztikailag is szignifikáns eltérést talált a megjelenő témák tekintetében a spanyol forrásszövegek és angol fordításaik között. A fordításokat nagyfokú információtöbblet, a személyekre utaló témák túlsúlya, az ezekhez kapcsolódó szintaktikai kategóriák eltérő eloszlása, valamint a fö lexikai elemek relatív gyakoriságának eltérései jellemezték. Az eredmények alapján arra a következtetésre jutott, hogy a célnyelvi szövegek feltehetően mondatról mondatra történő fordítás útján keletkeztek, $\mathrm{s}$ következésképp a forrásnyelvi szöveg tematikus szerkezete került átültetésre a fordításba. A szövegbeli módosulások szintaktikai szintü, (szöveg)felszíni változtatások voltak, és csupán a közvetlen, lokális szövegkörnyezetre voltak hatással. Globális tematikus stratégiára utaló megoldásokat nem talált, a fordítás pedig - Williams szerint - „természetellenes és elfogadhatatlan” volt (2004: 99). Kontextuális elemzései alapján Williams három olyan tematikus stratégiát azonosított, amelyek lehetővé teszik a forrás- és a célnyelvi szövegek közötti különbségek áthidalását: ezek a posztpozíció, a redundancia és a csökken- 
tett információs tartalom (2004: 99-100). Ezek segítségével minden nagyobb eltérés (többlet vagy hiány) korrigálható a fordításban, és természetes, a befogadók számára elfogadható minőségü fordítások készíthetők, amelyek megfelelnek a (spanyol) lexikai, szintaktikai és tematikus szerkezeti normáknak.

Williams 2005-ös tanulmánya orvosbiológiai témájú szakfolyóirat-cikkekröl szól. A cikkek eredményeket tárgyaló fejezeteiben (Discussion) a 'kutatás' ('research') és a 'kutató' ('researcher') szavak szemantikai mezőjét elemezte (angolspanyol fordításban). Jelentős stílusbeli eltéréseket talált az angol-amerikai és a spanyol szövegek között (2005: 156-157), amelyekböl az angol-amerikai stílust (pl. az angol személytelenebb hangvételét) jellemzően a fordítók átültetik a spanyol fordításba. Williams szerint az ilyen szövegtulajdonságok és a lehetséges korrekciós stratégiák ismerete nemcsak az anyanyelvükre dolgozó fordítók számára hasznos tudás, hanem azoknak a nem anyanyelvi beszélőknek is, akiknek idegen nyelven kell helytállniuk a szakmájukban.

Későbbi, 2007-es tanulmányában, korpuszalapú kontextuális elemzéseire támaszkodva Williams a különböző lexikai elemekkel kapcsolatos fordítási nehézségekben nyújt gyakorlati útmutatást is fordítóknak. Például az 'observar' ('to observe'/'megfigyelni') ige esetében azt találta, hogy angol cikkek spanyol fordításaiban ez a szó jóval többször szerepel, mint eredeti spanyol cikkekben. Adataiból arra következtet, hogy az orvosi szaknyelvben az 'observar' szó az angol 'observe' természetes fordítási megfelelője lehet. Más igék vonatkozásában azonban arra hívja fel a figyelmet, hogy a fordítónak ismernie kell a szóhoz kapcsolódó retorikai, szintaktikai és kollokációs megkötéseket, valamint az egyéb lehetséges lexikai alternatívákat, hogy biztosan a legmegfelelőbbet válassza ki és elkerülje az 'observar' ige túl sokszori (felesleges) ismétlését (2007: 85).

Jelentős mennyiségű adat áll rendelkezésre földrajzi tanulmányok szlovén $\rightarrow$ angol fordítási sajátosságairól is (Pisanski Peterlin 2008a, 2008b). Pisanski Peterlin (2008a) a szöveg tartalmi elemeinek makroszinten történő szerveződéséért felelös (szlovén) metadiskurzus angol nyelvi megfeleltetése (pl. this paper argues, as mentioned above, to conclude) során alkalmazott fordítási stratégiákkal foglalkozik. A szlovén földrajzi témájú cikkek angol fordításaiban szereplö metadiskurzushasználatot eredeti angol cikkekével veti össze. Két szinten vizsgálja a fordítói stratégiákat:

(1) feltárja az általános stratégiát (az eredeti szövegekben és a fordításokban azonosítva az egymásnak megfeleltethető kifejezéseket, a kihagyásokat és a betoldásokat) és

(2) összeveti az egymással megfeleltethető kifejezéseket és megvizsgálja, milyen változások történnek a fordításban.

Kutatási eredményei azt mutatják, hogy míg a szlovén forrásszöveg nem minden metadiskurzus-jelölőjét fordítják le, számos jelölőt toldanak be az angol fordításokba (pl. a following vagy az as follows kifejezéseket). Érdekes, hogy az eredeti 
angol cikkekböl álló korpuszban kétszer annyi metadiskurzus-jelölö van, mint az eredeti szlovénben. A célnyelvi összehasonlító korpusszal összevetve, az adatai alátámasztják a feltevését, hogy az eredeti angol szövegekben gyakoribb a metadiskurzus, mint a szlovénból angolra fordított cikkekben. Ez összhangban áll Mendiluce-Cabrera és Bermúdez-Bausela (2006), valamint Williams $(2004,2005)$ korábbiakban bemutatott kutatási eredményeivel, ahol azt láttuk, hogy a fordítók átültetik az angol fordításokba az anyanyelvük retorikai jellemzőit.

A tézismondat is olyan retorikai elem, aminek a használatában jelentősek a nyelvi és kulturális különbségek (Connor 1996, Kaplan 1966). Pisanski Peterlin (2008b) ezért megvizsgálta a használatát és megjelenési formáit földrajzi témájú folyóiratcikkekben (eredeti szlovénekben, ezek angol fordításaiban, valamint eredeti angol cikkekben). Azt találta, hogy eredeti angol cikkekben gyakrabban fordul elö, mint eredeti szlovén tanulmányokban, és hogy a szlovén cikkek angol fordításai inkább az eredeti szlovén cikkekkel mutatnak hasonlóságot (úgy, mint ahogy azt a korábbiakban bemutatott, a retorikai szerkezet egyes elemeit vizsgáló munkák eredményei is mutatták). Megvizsgálta a tézismondatok előfordulási helyét is a három alkorpuszban. A két, eredeti (angol és szlovén) szövegeket tartalmazó korpusz ebben is eltért egymástól: az angol fordítások inkább a szlovén eredetikkel mutattak hasonlóságot. Ahogyan az Williams kutatásainál is látható volt, Pisanski Peterlin is beszámol a korpuszában olyan fordítói változtatásokról (a szlovénről angolra fordításban), amik azt a célt szolgálják, hogy jobb, természetesebb célnyelvi szöveg szülessen.

\subsection{Az absztrakt múfaj fordításának sajátosságai}

Az absztrakt fontos szerepet tölt be a szakfolyóirat-cikkek feldolgozásában, ezért nem meglepő, hogy jelentős kutatói figyelem övezi a fordítását több tudományterületen is. López-Arroyo és Méndez-Cendón (2007) funkcionális megközelítésben mutatja be és hasonlítja össze a diagnosztikai képalkotás területén angolul és spanyolul írt orvostudományi cikkek absztraktjainak retorikai és frazeológiai szerkezetét. Azt vizsgálják, hogy hogyan kezeli a két nyelv az információtartalmat. Céljuk nagyon gyakorlati természetü: eredményeikkel a fordítók, szakírók és szaknyelvi képzésekben résztvevő hallgatók munkáját szeretnék támogatni, hogy megfelelő módon tudják kezelni az eltérő diskurzushagyományokból fakadó nehézségeket (2007: 503).

Vizsgálatuk az ún. „,informatív (vagy tudományos dolgozat) absztrakt” (angolul: informative (or RP) abstract) fordítási sajátosságainak feltárására irányul. $\mathrm{Az}$ informatív absztrakt egy rövid, pontos, objektív, teljes képet adó és jól követhetö összefoglalás, amely a tanulmány tartalmát formailag is követi, hogy az minél könnyebben érthető legyen (López-Arroyo és Méndez-Cendón 2007: 505). Jellegét tekintve eltér az ún. „leíró jellegü absztrakttól” (angolul: descriptive abstract), ami a tanulmány megközelítési módját, témáját és az adott kutatási térben elfoglalt helyét mutatja meg (2007: 505). Két folyóiratot hasonlítottak össze: az angol nyel- 
vü Radiology-t és a spanyol Radiología-t. Lexikai szempontból a Radiología absztraktjai jóval változatosabbak, feltehetően a spanyol nyelv természetéböl fakadóan. A spanyol szövegekben a lexikai ismétlések száma is alacsonyabb volt, mint az angolokban. Grammatikai szempontból az angol absztraktokban gyakori volt a múlt idejü szenvedő szerkezet használata, míg a spanyol szövegekben inkább nem ragozott igealakokból álló mellékmondatok szerepeltek. A szerzők szerint a Radiología folyóirat „távirati stílusa” (2007: 514) a szöveget dinamikusabbá teszi és aktívabban bevonja az olvasót, mint az angol múlt idejü megfogalmazásai. Frazeológiai és retorikai elemzéseik azt mutatják, hogy a spanyol szerzők nem minden esetben feltételeznek a magukéval azonos szakértelmet az olvasói oldalon. Ezzel szemben az angol szerzők a Radiology-ben nagyon sok szakterminust, komplex fönévi szerkezeteket használnak, ami arra enged következtetni, hogy olvasóközönségükről azt feltételezik, hogy ugyanolyan szaktudással rendelkeznek, mint ők. A retorikai felépítés tekintetében a Radiology absztraktjai szigorúan követik a folyóirat szerkesztési útmutatójában elöírt IMRAD szerkezetet (2007: 514; ami az Introduction-Method-Results-and-Discussion/Bevezetö-Módszerek-Eredményekés-Megvitatás rövidítése), a Radiología szerzői azonban nem ezt teszik. Az sem jellemző rájuk, hogy feltüntetnék az absztrakt egyes részeinek a címét. A spanyol korpuszban López-Arroyo és Méndez-Cendón (2007: 514-515) leíró jellegü absztraktra is talált példát (az esetek 12,7\%-ban), annak ellenére, hogy a szerkesztőbizottság kifejezetten informatív absztrakt készítését írta elö a szerzőknek.

Götz Andrea (2015) a fordítástudomány területén írt absztraktok müfaji elemzésével foglalkozik. A retorikai mozzanatszerkezetüket (Swales 1990) tárja fel, és azt vizsgálja, hogy (1) hogyan változik a szerkezetük magyar-angol fordításban és (2) milyen eltérések mutathatók ki a fordítás eredményeként keletkezett angol és az (eredetileg) angol nyelven írt absztraktok között. Meglepő módon elemzései nem mutatnak jelentős eltérést sem a magyar szövegek és angol fordításaik között, sem a fordított angol absztraktok és az eredeti angol absztraktok között. Csupán annyi különbség érzékelhető, hogy az Introduction (Bevezetö) mozzanat hangsúlyosabban jelent meg az eredeti angol absztraktokban, mint akár a magyar, akár a fordított angol változatokban. Götz Andrea ezt azzal magyarázza, hogy ez a mozzanat nagyon fontos szerepet játszik a kutatás pozicionálásában nemzetközi angol nyelvü tudományos fórumokon. A másik eltérést a módszerek és az eredmények közlésének módjában találta: a magyar absztraktok angol fordításaiban ezeknél a részeknél jelentősen megugrott a szószám.

\subsection{A tudományos konferencia-felhívás müfaj fordításának jellemzői}

Tack Erten (2012) azért vizsgálta a konferencia-felhívás müfaját, mert tapasztalatból látta, hogy minél jobban ismeri a fordító a műfaj szövegszintű és kulturális sajátosságait egy adott nyelvpár vonatkozásában, annál nagyobb az esélye arra, hogy meg tudja teremteni a fordítás során a kívánt funkcionális egyenértéküséget. 
Versenyképesség szempontjából a konferenciák esetében ez különösen fontos. Ezért egy kisméretü összehasonlító korpuszon azonosította az amerikai angol és a brazíliai portugál nyelvü konferencia-felhívásokban fellelhetö hasonlóságokat és különbségeket. Összességében sok hasonlóságot talált az angol és a portugál nyelvű felhívások között, de több olyan, elsősorban pragmatikai természetü különbséget is, amelyeket portugálról angolra fordítás során célszerü szem előtt tartani. Kutatási eredményei alapján a következő fordítói stratégiák alkalmazását javasolta annak érdekében, hogy a portugál $\rightarrow$ angol irányban a kívánt funkcionális ekvivalencia létrejöjjön:

(a) merjenek személyes hangnemben fogalmazni,

(b) kerüljék, vagy legalábbis csökkentsék az értékítéletet sugalló hangnemet a benyújtási és az elfogadási folyamat leírása során,

(c) a csoportcímeket a célnyelvi kulturális normáknak megfelelően adják meg és

(d) csökkentsék a felszólító módú igealakok használatát a szövegben.

\subsection{Pályázatok fordítása}

Tirkkonen-Condit (2001) finn anyanyelvüek egyéni és nemzetközi konzorciumos pályázatait (konkrétan projekt terveit, angolul: project proposals) vizsgálta, melyeket az Európai Bizottsághoz nyújtottak be. Azt találta, hogy az angol nyelvü pályázati anyagok sok tekintetben az angol-amerikai retorikai hagyományokat tükrözik, annak ellenére, hogy a finn retorikai normák ezektől jelentősen eltérnek (2001: 261). A finn szövegek ugyanis jóval implicitebbek és személytelenebbek. Általában a háttér-információkkal kezdődnek és az olvasóra bízzák, hogy a szövegből kikövetkeztesse a projekt céljait és a kutatók érdemeit. A szöveg lényege pedig általában a legvégén derül ki. Az öndicséret udvariatlanságnak számít, és a túl sok metaszöveget sem kedvelik, mert abból arra következtetnek, hogy az író alábecsüli az olvasók értelmi képességeit. Ezért fontos, hogy a finn anyanyelvü pályázó vagy fordító tudatában legyen ezeknek a retorikai különbségeknek, mert ellenkező esetben az angol szöveg bár grammatikailag helyes, mégsem fogja beváltani a hozzá füzött reményeket, csupán azért, mert retorikai szempontból nem felel meg a várakozásoknak.

Tirkkonen-Condit (2001: 262) arra is rámutatott, hogy mivel az EU-ban számos kultúra él együtt, az idők folyamán kifejlődött egy speciális, ún. Euró-retorika, mely a különböző nyelvi közösségek retorikai, lexikai és grammatikai sajátosságait ötvözi. Ezért az EU-t is célkultúrának tekinti, amely olyan saját „hibrid szövegekkel" (2001: 263) dolgozik, amelyek - jellegüket tekintve - eltérnek a többi, már létező nyelvi és retorikai normákkal bíró szövegtől ${ }^{4}$. Kutatási eredményei arra engednek következtetni, hogy a finn anyanyelvüek által írt angol szövegek is ilyen hibridnek tekinthetők, mivel egyszerre három különböző normát ötvöznek: 
(1) a finn (nemzeti) retorikai normát,

(2) a szándékolt célnormát (ez esetben az angol-amerikai tudományos retorikáét) és

(3) a hibrid célnormát (az Euró-retorikát).

Az EU-ban megjelenő finn nyelvü szövegek többsége fordítás angolról vagy franciáról és ezért fordításízüek. Bár Tirkkonen-Condit (2001: 264) nagy jelentőséget tulajdonít a hibrid szövegeknek, mégis átmeneti jelenségként/állapotként tekint rájuk, amit az eltérő diskurzus normák interakciója és együttélése hoz létre a nemzetköziesítés és az ebből eredő nagyarányú fordítási igény következtében. Meglátása szerint ezt az állapotot aztán egy újabb fázis követ, amikor a szóban forgó nyelvváltozatot ('́gy az Euró-retorikát is) már elfogadott, létező variánsként kezelik, saját nyelvi és retorikai jegyekkel.

\section{Diszciplináris különbségek a fordításban}

Az empirikus kutatások eredményei nem csupán a müfajok tekintetében mutatnak jellegzetes fordítási problémákat, hanem a különböző tudományterületeken is. A legnagyobb kihívást ebböl a szempontból az jelenti, hogy a különféle tudományterületeken dolgozó fordítók többsége nem az adott szakterületen dolgozó szakember vagy a terület kutatója, hanem olyan „kívülálló” (angolul: „outsider”), aki a „,bennfenteseknek” (angolul: ,insiders”; Collet 2016), vagyis a szakmabelieknek dolgozik. A tudományos érdeklődés legnagyobb része e téren is az orvosi, pontosabban az orvos- és egészségtudományi szakfordítást ${ }^{5}$ övezi (pl. Brøgger 2017, García Hidalgo és Dunham 1981, Jimenez-Crespo 2018, Mány 2019, Muňoz-Miquel 2018, Pietrzak 2015, Pilegaard 1997), de léteznek vizsgálatok a gazdaságtudományi szakfordítás (pl. Fuertes-Olivera és Pizarro-Sánchez 2002, Stolze 2003), a nőtudományok (pl. Farahzad 2003), az irodalom- és kultúratudományok (pl. Bennett 2006), a filozófiatudomány (pl. Albert 2000, 2001), a széles értelemben vett társadalomtudományok terén is (pl. Collet 2016, Jacquemond 2015, Kemppanen 2004) és a müszaki tudományok terén is (pl. Meade 2011, López-Rodríguez és Tercedor-Sánchez 2008).

\subsection{Az orvos- és egészségtudományi szakfordítás}

A szakfordításnak ez a területe hosszú múltra tekint vissza (ld. Pilegaard 1997: 160-161, Fischbach 1986, 1993 és Muňoz-Miquel 2018 áttekintését). Nem véletlenül tartják a tudományos szakfordítás „leguniverzálisabb és legősibb” fajtájának (Fischbach 1986: 16). Ennek számos oka közül talán a legfontosabb, hogy

(1) tárgya (az emberi test) univerzális,

(2) szerepet játszik az orvostudományi ismeretek felhalmozásában és terjesztésében (Muňoz-Miquel 2018: 25), 
(3) forrásai igen sokszínűek (folyóiratok, enciklopédiák, tankönyvek, szótárak, orvosok, könyvtárosok) és

(4) terminológiája egységes (különösen a nyugati nyelveken, ahol a szakterminusok túlnyomó többsége latin vagy görög eredetü).

Muňoz-Miquel (2018: 25) szerint az orvos- és egészségtudományi szakfordítás nemcsak a legősibb fordítási tevékenység, hanem a legtöbb szakterülettel és müködési kontextussal rendelkező is: az egészségügytől a klinikai kutatásokon keresztül az orvosi praxison át a gyógyszerkutatásig mindenhol jelentős a fordítási tevékenység. Óriási mennyiségü információt fordítanak nap mint nap, számos nyelvre, a legkülönbözőbb intézményi környezetekben (egészségügyi szervezetekben, gyógyszer laboratóriumokban, kutatóközpontokban, egyetemeken, kórházakban stb.).

Bár a területnek nagy hagyományai vannak, a globalizáció, a technika és a különféle technológiák gyors fejlödése ezt sem kíméli a kihívásoktól. A latin után az angol lett a nemzetközi kommunikáció nyelve az orvos- és egészségtudományban; az új kutatási eredményeknek és felfedezéseknek köszönhetően évről évre újabb és újabb szakkifejezések és rövidítések jelennek meg; nem minden fogalomnak, terminusnak van célnyelvi megfelelöje; és a szakzsargont, a szakterminusokat a nem anyanyelvi beszélők gyakran helytelenül használják (Pilegaard 1997: 162163). A fordítási problémák szempontjából legtöbbet kutatott múfajok között megtalálható az esettanulmány, a kórleírás, a kezelési jelentés, a szakfolyóiratcikk, a disszertáció, az orvosi szakkönyv és tankönyv, valamint - a szóbeli müfajok közül - érdekes módon, a beszéd (az előadás) müfaja.

A fordítási tevékenységet ezen a területen nem csupán „kívülállók” végzik. A fordítók között vannak a célnyelvet jól beszélő szakmabeliek (egészségügyi dolgozók, orvosok és kutatók) éppúgy, mint nyelvész végzettségü tapasztalt, vagy akár képzett fordítók is (olyanok, akik már kifejezetten fordítói/fordítástudományi diplomával rendelkeznek ${ }^{6}$ ). Mindkét típusra jelentős kutatói figyelem összpontosul - nem csupán a fordítástudomány, hanem a szaknyelvkutatás területén is - mind a fordítások minősége (erősségek, gyengeségek), mind pedig a fordítói kompetenciák és készségek terén (áttekintés ezekről Muňoz-Miquel (2018), valamint Wright és Wright (1993) munkájában olvasható).

Érdekes módon a tanulmányok többsége személyes tapasztalatokat dolgoz fel. Muňoz-Miquel (2018: 45-46) munkája ezzel szemben szisztematikus adatelemzésen alapul: feltárja, hogy (1) az orvos- és egészségtudományi szakfordítók milyen képzési és társadalmi-szakmai háttérből származnak, és (2) hogy a nyelvész, ill. az orvosi/kutatói háttérből érkező fordítók fordítói gyakorlatában és képzési igényeiben milyen különbségek érhetők tetten. Vizsgálatai azt mutatják, hogy bár a szakterületen dolgozó fordítók nagyon különböző képzési háttérböl érkeznek, a többségük inkább nyelvész végzettségü. Magas százalékban talált azonban az alanyai között természettudományos területekről származó fordítókat is (orvosi egyetemet végzetteket vagy biológusokat), ami jól bizonyítja az orvosi- és egészségtu- 
dományi szakfordítói tevékenység széles beágyazódását (2018: 47). A két fordítói kör jellemzően eltérő kihívásokkal találja szembe magát. A nyelvész/fordító végzettségű szakemberek nehézségei általában fogalmi és terminológiai természetüek, míg az orvosi/egészségtudományi háttérrel rendelkezőknek többnyire a fordítást támogató eszközök alkalmazásában, valamint az anyanyelv megfelelő igényességgel történő használatában vannak korlátaik. Eltéréseik ellenére az orvosi- és egészségtudományi szakfordítók esetében Muňoz-Miquel (2018: 48) tanulmánya számos jellegzetes - mindkét fordítói csoportról egyaránt elmondható - szakmai/társadalmi vonást azonosít, melyeket a következő hét pontban lehet összegezni:

- nagy tapasztalattal rendelkeznek a szakterületen,

- egyszerre sokféle megrendelőnek dolgoznak (még gyógyszeripari laboratóriumoknak is),

- számos múfajt fordítanak (melyek legtöbbje a gyógyszeripari és a kutatási szektorhoz kötődik),

- változatos dokumentációs forrásokat alkalmaznak, s következésképp

- jelentős eltéréseket mutatnak a fordítási problémák megoldása során használt források és eszközök tekintetében,

- többségük kizárólag ezen a szakterületen dolgozik, amiből arra lehet következtetni, hogy

- az orvos- és egészségtudományi szakfordításból (önmagában) meg lehet élni.

\subsection{Gazdasági és gazdaságtudományi szakfordítás}

A fentiektől eltérő sajátosságok és kihívások jellemzik a gazdasági és gazdaságtudományi szakfordítást. Stolze (2003: 187) szerint a területen történő fordítási tevékenységben a legnagyobb kihívást az egyszerre több nyelvi szinten is fellelhető „homályosság” (angolul: „vagueness”) kezelése jelenti. Meglátása szerint a gazdasági szövegek pragmatikai, szemantikai, terminológiai és fogalmi szempontból is gyakran homályosak (mert pl. speciális fogalmakra általános nyelvi megfogalmazásokat használnak, vagy mert a fogalmi apparátusuk kulturálisan kötött), s ezért fennáll a veszélye annak, hogy a fordító félreérti a szöveget. A fordítónak tehát már-már „társszerzőként” kell dolgoznia, a háttértudása mozgósításával ahhoz, hogy a fordítása megfelelő legyen. Ez adott esetben nem csupán (gazdasági) szakterületi tudás szükségességét jelenti, hanem a célnyelvhez kapcsolódó kommunikációs szokások mélyreható ismeretét is (2003: 202).

Ehhez a kérdéskörhöz szorosan kapcsolódik még egy nehézség, mégpedig a gazdasági szövegekben gyakran fellelhető ún. terminológiai metaforák problematikája ${ }^{7}$. Fuertes-Olivera és Pizarro-Sánchez (2002) korpuszalapú vizsgálata célzottan a terminológiai metaforával mint kognitív és esztétikai eszközzel foglalkozik. Lakoff és Johnson (1980) metaforaelméletéből indulnak ki, miszerint a metaforikus szerkezetek mögött fogalmi metaforák állnak, melyek segítségével képesek vagyunk 
konceptualizálni a világról alkotott tudásunkat. A metafora megismerésben betöltött szerepét már Arisztotelész is felismerte, de az ókori retorikában elsősorban az esztétikai-stilisztikai funkciójával éltek, illetve a tömörítés egyik eszközeként alkalmazták. Fuertes-Olivera és Pizarro-Sánchez az elemzéseik alapján arra jöttek rá, hogy azok a metaforák, amelyek újfajta hasonlóságot teremtenek, jó eséllyel elöbb vagy utóbb szakterminusokká válnak. Ezért a fordítónak fontos feladata van abban, hogy olyan célnyelvi megoldást találjon rájuk, ami egyfelöl képes terminusként funkcionálni (tehát megőrzi a metafora konceptuális funkcióját) és mellette ugyanolyan meglepö/érdekes/szép stb. a befogadók számára, mint az eredeti metafora a forrásnyelvi közönség számára (vagyis hatásában megörzi az esztétikai funkcióját).

Példaként angol nyelvü gazdasági szövegek spanyol fordításaiban mutatják be az ,inflation” (magyarul: infláció) szó spanyol fordításait. A leírás szerint a fogalmat az elemzett szövegek, mint 'lovat', 'motort', 'betegséget', 'ellenséget' és 'rablást' konceptualizálják. A kutatásukban résztvevő válaszadók szerint a spanyol fordítások az eredeti (angol) szövegekhez hasonlóan konceptualizálták a fogalmat, a metaforikus kifejezések pedig segítettek vizuálisan megjeleníteni az inflációt mint jelenséget (Fuertes-Olivera és Pizarro-Sánchez 2002: 63-64). A fordítási módszerek elemzése alapján arra a megállapításra jutottak, hogy szakszövegek esetében célravezető a szó szerinti fordítás módszere, mivel így új, könnyen érthető nyelvi metaforák, ún. „hasonlóságot teremtő metaforák” (angolul „similaritycreating metaphors") jönnek létre, melyek aztán fokozatosan szakterminusokká válhatnak. Ez gyakori módja a tudományos-technikai ismeretek és szakkifejezések terjesztésének. A fordítók kreatív részesei a folyamatnak, a fordítás pedig ,szerepet játszik a terminológiai standardizációban és a terminusalkotásban" (2002: 64; a szerző fordítása). Ezzel Fuertes-Olivera és Pizarro-Sánchez vizsgálatai is alátámasztják a fordítás kulcsfontosságú szerepét a tudományos gondolkodás alakulásában és a tudományos eredmények disszeminációjában.

\subsection{Szakfordítás egyéb tudományterületeken}

A társadalomtudományok területén végzett szakfordítói tevékenységgel általánosabb értelemben, majd konkrétabban fordítástudományi cikkek elemzésével Collet (2016) foglalkozott. Abból a feltevésből indult ki, hogy a társadalomtudományi szakszövegek többnyire olyanok, hogy - speciális terminológiájuk vagy szöveghagyományaik révén - vagy segítik, vagy éppen ellenkezőleg, akadályozzák az olvasót abban, hogy a bennük közölt tartalmat megértse. Állítását egy nyelvészeti szempontú fordításelemzéssel igazolta. Kutatásában egy több mint 200 szemantikai jelölőből álló korpuszt vizsgált, melyeket angol és francia nyelvü, a Meta címü nemzetközi fordítástudományi folyóiratban megjelent cikkekből állított össze. A szöveghagyományok szerepének kimutatására a szövegbeli hivatkozásokat elemezte (hogy miként építik be a szerzők a saját gondolatmenetükbe/szövegükbe más szerzők gondolatait/szövegeit) ${ }^{8}$. Az eredmények szépen rávilágítanak arra, hogy a szaknyelvi szövegalkotásban, és különösen a tudományos szakszöveg-al- 
kotásban mennyire meghatározóak a szakterület (formai) szöveghagyományai. Korpusza alapján felállítja a szövegekben fellelhető szemantikai jelölök tipológiáját és bemutatja, hogy ezek miként segítik a szakfordítót a fordítás-elökészítés fázisában, különösen akkor, ha „kívülálló” a területen. Ebben az esetben ugyanis nehézsége akadhat egy olyan szöveg megértésében, amelyet (eredetileg) a szakterület képviselője a többi „,bennfentesnek” (szakmabélinek) írt. Collet (2016) vizsgálati eredményei szerint a hivatkozások egyszerre több funkciót is betölthetnek a szakszövegben. Részt vesznek

- az intellektuális tulajdonítás kifejezésében;

- a társadalmi tudásteremtésben;

- a szöveg meggyőző erejének biztosításában;

- bizonyos szakterminusok jelentésének tisztázásában;

- az ún. „kettős párbeszédminőség” (angolul „dual dialogic quality”; Collet 2016) megalkotásában (azáltal, hogy korábbi szövegek szerzőire utalnak, de az olvasóval is interakcióba lépnek, amikor a bennük esetlegesen felmerülő kérdésekre választ adnak, vagy - igény esetén - pontosabb szemantikai vagy konceptuális információt szolgáltatnak); s következésképp

- a szöveg követhetőségének biztosításában (amit egy szük, a tudományterületen jártas olvasóközönség számára írtak).

Szintén a társadalomtudományokhoz kapcsolódóan Farahzad (2003) a nőtudomány területén készült angol-perzsa fordításokat elemezte, különös tekintettel a feminista elméletekről szóló szövegekre. Arra volt kíváncsi, hogy a fordítók manipulálják-e a szöveget, és ha igen, hogyan és miért keletkeznek manipulatív eltolódások a fordításban. A kutatásában tíz tapasztalt női és tíz szintén tapasztalt férfi angol-perzsa fordító vett részt. Elemzései azt mutatják, hogy a manipulációt ebben a fordítási kontextusban elsősorban ideológiai szándékok vezérlik: vannak, akik szándékosan nem fordítanak le egy-egy lexikai elemet, vagy szintaktikailag módosítják a szöveget (pl. hogy homályossá tegyék), és vannak olyanok is, akik ideológiai megfontolásból manipulálják a szöveg tartalmát. A manipulációt Farahzad (2003: 279-280) ezért interpretációs stratégiaként értelmezi, és mivel az általa vizsgált fordítók interpretációi sem mentesek a manipulációtól, jelentős menynyiségű szövegben talált példát manipulációs eltolódásokban megnyilvánuló tartalommódosulásokra.

Az ideológia szerepével Kemppanen (2004) is foglalkozott a politikatudományon belül finn politikatörténeti szövegek fordításának korpuszalapú elemzése során. Azt vizsgálta, hogy a kulcsszavak használatában (fordított és nem fordítás eredményeként keletkező orosz és finn szövegek esetében) megjelenik-e bármilyen ideológia. Kulcsszóként azokat a szavakat kezelte, amelyeknek szociológiai szempontból valamilyen jelentőségük van (pl. a „ystävyys”/,,barátság” szó). Érdekes módon az eredmények jelentős eltéréseket mutatnak a fordítások és az eredeti finn szövegek között, például a szó lexikai mintázataiban, amelyek a fordításokban 
jóval produktívabbak (szóösszetételek és szóklaszterek alkotásában), mint az eredeti szövegekben. A fordításokban a mondatok alanya együttműködő szereplőként jelenik meg (aki együttmüködik a közös cél, a barátság megvalósításában), miközben az eredeti szövegekben a mondat cselekvő alanya egyedül cselekszik (ez is magyarázza ezekben a szövegekben a ,ystävyys” szó ritkább elöfordulását). Gyakran tapasztalja, hogy amikor a szó megjelenik, az adott kontextusban negatív szemantikai prozódia társul hozzá.

Bennett (2006) az irodalom- és kultúratudomány területén született angol és portugál nyelvü esszékből vett részleteket elemzett. Három jelentős eltérést talált a korpuszai között:

(1) a müfaj felszíni hasonlóságai ellenére, a két nyelven a szövegrészletek egymástól eltérő világképet tükröztek: míg az angol szöveg egy megfigyelhető, elemezhető és leírható objektív valóság létezéséről ad számot, a portugál változat nem mutat érdeklödést a fizikai világ iránt;

(2) a portugál szöveg az angol tudományos diskurzustól idegenül kezeli a forma és a tartalom közötti hagyományos distinkciót: az angolban az információ transzparens és könnyen hozzáférhetö, a portugálban nem ilyen evidens és nem könnyen hozzáférhetö;

(3) a jelentésközvetítéshez való hozzáállás eltérő a két nyelven: míg az angol szerző lineárisan halad előre és erősen kontrollálja a szöveg értelmét (szigorúan denotatív módon használja a terminusokat, egyszerű szintaxist alkalmaz és kerüli a kétértelmüséget), a portugál szerző kevésbé lineárisan fogalmaz, és nem kontrollálja annyira az üzenetet (kétértelmüen fogalmaz, paradoxonokkal és analógiákkal dolgozik, összetett mondatokban fogalmaz). Az utóbbiak mind olyan jegyek, amelyek az angol olvasó számára kaotikussá, nehezen követhetővé teszik a szöveget.

Hasonló megfigyelésekről olvashatunk Albert Sándor (2000, 2001) munkájában a filozófiai szövegek fordítása kapcsán. A filozófiai szövegeket az ún. elméleti vagy teoretikus diskurzus szövegtípusba sorolja, és a tudományos diskurzus nagyon különleges fajtájának tekinti, mivel - ahogy írja - „e szövegtípus fordításának megvannak a maga specifikus (szemantikai, szintaktikai, stilisztikai stb.) problémái” (2000: 5). Fordítói és kontrollszerkesztői tapasztalata alapján az a meggyőződése, hogy a filozófiai (és elméleti) diskurzus fordításával kapcsolatos problémákat (az ideológiai és politikai szövegekhez hasonlóan) az okozza, hogy ezek természetüknél fogva argumentatív, metaforikus és leíró jellegü szövegek, s következésképp ,érthetetlenek” (2000: 6) és „fordíthatatlanok” (2000: 10) is. A filozófiai szöveg megértése elözetes filozófiai ismereteket feltételez, nyelvezete elvont, metaforikus, neologizmusokat tartalmaz, olyan szavakat, fogalmakat használ, amelyek jelöltje/referense nem mindig egyértelmü azonnal, számos szakkifejezést maga a szerző talál ki (2000: 6). E szövegek fordítása ezért még a profi fordító számára is komoly kihívást jelent. 
Albert Sándor ezért Martin Heideggernek, a kutatók által a „fordíthatatlanság archetípusaként" (2000: 9) emlegetett Lét is idő címü müve magyar, francia, angol, olasz és spanyol fordítását elemezte. Elmondása szerint a fordítók időnként kifejezetten kerülőutakon át, meglepő és időigényes módszerekkel jutnak el a kívánt megoldásig a fordításban (pl. az adott szakkifejezést elöször egy modern nyugati nyelvre fordítják, utána ógörögre vagy latinra, majd egy távol keleti nyelv középkori változatára, s csak ezt követően annak modern verziójára). Elismerően nyilatkozik Freud különleges módszeréről is, aki nem mondatról mondatra haladt a fordítás során, hanem elolvasott egy bekezdést az eredeti szövegből, majd becsukta a könyvet, átgondolta, hogy egy német szerző hogyan fogalmazta volna meg ezeket a gondolatokat, majd ezt a változatot vetette papírra.

Ahogy a fentiekből is látható, a vizsgált változók és szövegfajták még egy-egy diszciplínán belül is igen változatosak. Ebböl következően a tudományos szövegek célnyelvi megfeleltetése során felmerülő fordítási nehézségek is széles skálán mozognak és a kommunikáció és a szövegalkotás több szintjét is érintik a szóválasztástól (különösen a különféle lexikai elemek és kombinációik megfeleltetésétöl: pl. Krein-Kühle 2011, Méndez-Cendón 2009, Williams 2007) és a terminológiai kérdésektől kezdődően (pl. Fernández-Silva és Kerremans 2011, Pilegaard 1997, Rogers 2012), az explicitációs/implicitációs döntéseken keresztül (pl. Jawad 2014, Jimenez-Crespo 2018, Krüger 2016) egészen az olyan szövegszintü jelenségekig, mint az információs szerkezet (pl. Williams 2005, 2006) vagy a forrásnyelvi szövegszerkezet újrateremtése a célnyelven (pl. Aksoy 2001, Pisanski Peterlin 2008a, López-Arroyo és Méndez-Cendón 2007). Ezek mellett jelentős mennyiségü kutatási eredmény áll rendelkezésünkre a szöveg társadalmi beágyazódásához kapcsolódó olyan kérdésekről is, mint az ideológia fordításának lehetőségei és manifesztációi (pl. Farahzad 2003, Sánchez 2011) vagy a kultúrák közötti különbségek kezelésének módjai (pl. Gil-Bardají 2009, Hamdan és Natour 2014, Kastberg 2007). A fordítási problémák eddig feltárt megoldási lehetőségeiről a következő, összegző részben lesz szó.

\section{5. Összegzés: a tudományos szakfordítás egyedi kihívásai és minőségi követelményei}

A kutatók által vizsgált nyelvek rendszerbeli különbségei miatt (ld. 2. rész 1. táblázata) a tudományos szaknyelvi fordítás vonatkozásában reménytelen vállalkozás volna általánosítható következtetéseket levonni a fordítási nehézségek kiküszöbölésére irányuló konkrét fordítói stratégiákról. A bemutatottak alapján azonban (1) körvonalazódni látszanak olyan, kifejezetten a tudományos szakfordításban jelentkező kihívások/problémaforrások, amelyek az érintkező nyelvek rendszerbeli sajátosságaitól függetlenek, s potenciálisan megoldásra, speciális fordítási stratégiák alkalmazására várnak, (2) meghatározható azon kompetenciák köre, amelyek szükségesek ahhoz, hogy a fordítás nyelvi és szakmai/tudományos szempontból is 
megállja a helyét és (3) azonosíthatók az ezekhez kapcsolódó alapvető fordítói/ fordítási minőségek.

A 2-4. részekben láthattuk, hogy a tudományos szakfordítás a fordítói tevékenység egyik talán legtöbb kihívást okozó, számos problémát felvető területe. Ilyen problémaforrás lehet például bármely

- tudományos fogalom és terminus technicus,

- tudományos/terminológiai metafora (ami nem azonos az irodalmi metaforával: 1d. 4.2. rész),

- hivatkozás (ha pl. a hivatkozott szerző neme nyelvileg jelöletlen; ld. 4.3. rész),

- ideológia,

- kulturális jelenség,

- speciális (mennyiségű vagy minőségű) információ,

- szövegszerkezeti jellemző",

- regiszterjellemző (pl. szerzőre vagy olvasóra orientált regiszter; Krein-Kühle 2011: 391),

- stílusjegy (pl. forrás- vagy célnyelvi kulturális norma; Aksoy 2001) és

- a tudományos szakszerüség (az absztrakció) mértékének (ld. 2.2. rész végén), célnyelvi megfeleltetése.

A lehetséges problémaforrások kezeléséhez a tudományos szakfordítónak speciális kompetenciákra van szüksége, amelyek már nem csupán a nyelvi és kulturális transzfert biztosítják, hanem a tudományos ismeretek/eredmények megfelelően szakszerü közvetítését is. A kutatási eredmények alapján ezek közül a legfontosabbak

- a szakterületi/tudományos ismeret/kompetencia,

- szaknyelvi kompetencia (forrás- és célnyelven),

- szakfordítói kompetencia,

- az interkulturális kompetencia, valamint a diskurzuskompetencián belüli

- szakterület-specifikus müfaji (Tack Erten 2012) és

- müfaj-transzfer kompetencia (Károly 2008).

Mindezek birtokában lesz képes a fordító olyan célnyelvi változat megalkotására, amely megfelel a tanulmányom elején megfogalmazott feltételnek: hogy a fordítás funkcionálisan egyenértékű legyen az eredetileg a célnyelven született szövegekkel, és hogy a benne megjelenő tudás és ismeretanyag hiteles és versenyképes legyen. Az angol nyelvre történő fordítás esetében ez különösen (de nem kizárólag) a következő feltételek teljesülését jelenti: a keletkező szöveg legyen

- világos, explicit és egyértelmü,

- megfogalmazásaiban tömör,

- tartalmában hü a forrásszöveghez, 
- semleges hangvételü,

- objektív,

- lexikai szempontból megfeleltethető a forrásszöveg fogalmaival és terminusaival (Chandra Rose 1994: 63, idézi Montgomery 2000: 276),

- szövegszinten „funkcionálisan konstans és ekvivalens” (Krein-Kühle 2011),

- alkalmas a szerző és a célnyelvi olvasó közötti szakmai-tudományos kommunikáció megvalósítására (Stolze 2003: 187).

A tanulmányban bemutatott kutatások arra engednek következtetni, hogy a fenti feltételek akkor tudnak teljesülni, ha a fordító tudatában van nem csupán az országhatárokon és kultúrákon átívelő tudomány közvetítő funkciójának (Olohan és Salama-Carr 2011: 187), hanem annak a ténynek is, hogy munkájával aktív szerepet játszik (és a történelem során mindig is aktív szerepet játszott) az emberiség megismerési folyamataiban, tudásalkotásában és a tudomány fejlődésében. Nincs, és sosem volt hálás dolga, hiszen ez óriási felelősség, miközben akkor jár el helyesen, ha a fordítása olyan, mint az eredeti célnyelvi tudományos szövegek, de önmaga eközben láthatatlan marad.

\section{Jegyzetek}

${ }^{1}$ A tanulmányban szereplő fordítások a szerző fordításai. Az idézet eredeti szövege: ’[g] ood scientific writing is not a matter of life and death; it is much more serious than that" (Day és Gastel 2006/2016: ix).

${ }^{2}$ Fontos megjegyezni, hogy az empirikus kutatások mellett a tudományos szakfordítás koncepcionális és történeti kérdéseivel, valamint a tudomány fejlődésében betöltött szerepével számos elméleti munka is foglalkozik. Ezekről bővebben Károly (2019) munkájában olvashatunk.

3 „A nemzetközi angol az angol nyelv olyan standard változata, amelyet leegyszerüsített nyelvtani szabályok, tömör és világos, a kétértelmüséget mellőző szerkezet, valamint kötött terminológia, a kollokvializmusok, a szleng és az idiomatikus megfogalmazások hiánya jellemez. A nemzetközi angol diatopikus változatokat sem tartalmaz." Az idézet eredeti szövege: "IE is a standard variety of the English language characterized by simplified grammatical rules, a concise and clear structure avoiding ambiguity along with a fixed terminology, a lack of colloquialisms, slang or any other idiomatic variants. Diatopic variants are also excluded from IE." (Mendiluce-Cabrera és Bermúdez-Bausela 2006: 453)

${ }^{4}$ Schäffner és Adab (2001: 169) meghatározása szerint a hibrid szöveg „fordítási folyamat eredménye. Sajátosságai 'nem helyénvalók'/'furcsák'/'szokatlanok' a befogadó kultúra, vagyis a célkultúra számára. Ezek a sajátosságok azonban nem a fordítói kompetencia hiányából fakadnak és nem is a fordításízúség ('translationese') esetei, hanem tudatos és szándékos fordítói döntések eredményei. Bár az ilyen szöveg még nem egészen a célkultúra sajátja (mert nem követi a szokásos normákat és hagyományokat), de az mégis elfogadja, mivel képes betölteni funkcióját az adott kommunikációs helyzetben (legalábbis egy bizonyos időre)." 
Az idézet eredeti szövege: a hybrid text is "a text that results from a translation process. It shows features that somehow seem 'out of place'/'strange'/'unusual' for the receiving culture, i.e., the target culture. These features, however, are not the result of lack of translational competence or examples of 'translationese', but they are evidence of conscious and deliberate decisions by the translator. Although the text is not yet fully established in the target culture (because it does not confirm to established norms and conventions), a hybrid text is accepted in its target culture because it fulfils its intended purpose in the communicative situation (at least for a certain time)."

${ }^{5}$ Az angol nyelvü szakirodalomban a terület megnevezésére a „medical translation” kifejezést használják.

${ }^{6}$ A kifejezetten az orvos- és egészségtudományi szakfordításra specializálódott egyetemi képzési programok relatíve új keletűek, a nemzetközi színtéren többségükben az 1990-es években jelentek meg.

${ }^{7}$ A terminológiai metafora a tudományos metaforák egyik fajtája. Fontos megjegyezni, hogy a tudományos metafora nem azonos az irodalmi metaforával. Nasser (2014) szerint, míg az irodalmi metaforák elsősorban díszítik és színessé teszik a szöveget, a tudományos metaforák feladata - hasonlóság alapján - az információátadás. A fordítók általában megtalálják a tudományos metafora célnyelvi megfelelőjét, de előfordulhat olyan is, hogy nincs ilyen az adott nyelven. Ilyen esetekben a fordító helyettesítheti egy másik olyan metaforával, ami nem ütközik a célnyelvi kultúrával, vagy használhat helyette egy hasonlatot, magyarázó mellékmondatot, lábjegyzetet stb.

${ }^{8}$ A hivatkozások fordításának egy másik kérdésével, a hivatkozott szerző nemének lehetséges azonosítási módjaival foglalkozik Hamdan és Natour (2014), olyan szövegek esetében, ahol a nem nyelvileg nem jelölt (pl. az idéző igék ragozott alakjaiban).

${ }^{9}$ Baumgarten, House és Probst (2004: 104-105) arra mutatott rá, hogy az angol - mint a tudományos kommunikáció lingua franca-ja - olyan erövel hat a többi nyelv szövegszerkesztési normáira, hogy azok fokozatosan átveszik a jellemzőit. Ennek a folyamatnak az eredményeként a forrás és a célnyelvi normák idővel egyre inkább közelednek egymáshoz.

\section{Irodalom}

Aksoy, B. 2001. Aspects of Textuality in Translating a History Book from Turkish into English. Babel Vol. 47. No. 3. 193-204.

Albert S. 2000. Filozófiai szövegek fordítása 1. rész. Fordítástudomány 2. évf. 2. szám. $5-23$.

Albert S. 2001. Filozófiai szövegek fordítása 2. rész Forditástudomány 3. évf. 1. szám. $5-25$.

Al-Hassnawi, A. 2007. Aspects of Scientific Translation: English into Arabic Translation as a Case Study. https://www.translationdirectory.com/article10.htm

Baumgarten, N., House, J., Probst, J. 2004. English as a Lingua Franca in Covert Translation Processes. The Translator Vol. 10. No. 1. 83-108. https://doi.org/10.1080/135565 09.2004.10799169

Beaugrande, R. de 1997. New Foundations for a Science of Text and Discourse: Cognition, Communication, and Freedom of Access to Knowledge and Society. New Jersey: Ablex Publishing Corporation. 
Bennett, K. 2006. Critical Language Study and Translation. The Case of Academic Discourse. In: Duarte, J. F., Assis Rosa, A., Seruya, T. (eds) Translation Studies at the Interface of Disciplines [Benjamins Translation Library 68]. Amsterdam, Philadelphia: John Benjamins. 111-127.

Bennett, K. 2008. English Academic Discourse: Its Hegemonic Status and Implications for Translation. Doktori disszertáció. Universidade de Lisboa, Faculdade de Letras, Programa em Estudos Comparatistas.

Bennett, K. 2011. The Scientific Revolution and its Repercussions on the Translation of Technical Discourse. The Translator Vol. 17. No. 2. 189-210. https://doi.org/10.1080/ 13556509.2011.10799486

Bennett, K. 2012. English Academic Discourse: Hegemonic Status and Implications for Translation (with Particular Reference to Portuguese). Saarbrücken: Lambert Academic Publishing.

Bowker, L. 2016. The Need for Speed! Experimenting with "Speed Training" in the Scientific/Technical Translation Classroom. Meta Vol. 61(Hors série). 22-36. https://doi. org $/ 10.7202 / 1038683$ ar

Brøgger, M. N. 2017. When Translation Competence is Not Enough: A Focus Group Study of Medical Translators. Meta Vol. 62. No. 2. 397-414. https://doi.org/10.7202/1041030ar Camara, L., Espasa, E. 2011. The Audio Description of Scientific Multimedia. The Translator Vol. 17. No. 2. 415-438. https://doi.org/10.1080/13556509.2011.10799496

Collet, T. 2016. Intertextuality in Specialised Translation: Citations as Semantic Markers in Social Science. The Journal of Specialized Translation No. 26. 72-95. (2016 július).

Connor, U. 1996. Contrastive Rhetoric. Cambridge: Cambridge University Press.

Day, R. A., Gastel, B. 2006/2016. How to Write and Publish a Scientific Paper. Cambridge: Cambridge University Press.

Farahzad, F. 2003. Manipulation in Translation. Perspectives: Studies in Translatology Vol. 11. No. 4. 269-281. https://doi.org/10.1080/0907676X.2003.9961480

Fernández-Silva, S., Kerremans, K. 2011. Terminological Variation in Source Texts and Translations: A Pilot Study. Meta Vol.56.No. 2.318-335. https://doi.org/10.7202/1006179ar

Fischbach, H. 1986. Some Anatomical and Physiological Aspects of Medical Translation. Lexical Equivalence, Ubiquitous References and Universality of Subject Minimize Misunderstanding and Maximize Transfer of Meaning. Meta Vol. 31. No. 1. 13-27. https://doi.org/10.7202/002743ar

Fischbach, H. 1993. Translation, the Great Pollinator of Science. A Brief Flashback on Medical Translation. In: Wright, S. E., Wright L. D. (eds) Scientific and Technical Translation. Amsterdam, Philadelphia: John Benjamins. 89-100. https://doi.org/10.1075/ata. vi.08fis

Franco Aixelá, J. 2004. The Study of Technical and Scientific Translation: An Examination of its Historical Development. The Journal of Specialised Translation No. 1. 29-49. (2004 január).

Fuertes-Olivera, P. A., Pizarro-Sánchez, I. 2002. Translation and 'Similarity-creating Metaphors' in Specialized Languages. Target Vol. 14. No. 1. 43-73. https://doi.org/10.1075/ target.14.1.03fue

Garcia Hidalgo, I., Dunham, G. 1981. An Experiment in English-Spanish Automated Translation of Medical Language Data. Methods of Information in Medicine Vol. 20. No. 1. 38-46. https://doi.org/10.1055/s-0038-1635288 
Gerzymisch-Arbogast, H. 1993. Contrastive Scientific and Technical Register as a Translation Problem. In: Wright, S. E., Wright, L. D. (eds) Scientific and Technical Translation. Amsterdam, Philadelphia: John Benjamins. 21-52. https://doi.org/10.1075/ata.vi

Gil-Bardají, A. 2009. Academic Discourse and Translation from Arabic. A Case Study from the Spanish Tradition. Babel Vol. 55. No. 4. 381-393. https://doi.org/10.1075/ babel.55.4.05gil

Götz A. 2015. Magyar és angol absztraktok retorikai szerkezetének elemzése. Forditástudomány 17. évf. 2. szám. 88-116.

Heltai P. 2008. Lexikai átváltási műveletek irodalmi és szakfordításban. Forditástudomány 10. évf. 1. szám. 5-17.

Hoorickx-Raucq, I. 2005. Mediating the Scientific Text: A Cultural Approach to the Discourse of Science in Some English and French Publications and TV Documentaries. The Journal of Specialised Translation No. 3. 97-108. (2005 január).

Jacquemond, R. 2015. Translating Social Sciences into Arabic: The Case of Pierre Bourdieu. The Translator Vol. 21. No. 2. 189-209. https://doi.org/10.1080/13556509. 2015.1069042

Jakobsen, A. L. 1993. Translation as Textual (Re)production. Perspectives: Studies in Translatology Vol. 2. 155-165. https://doi.org/10.1080/0907676X.1993.9961209

Jawad, H. A. 2014. Shifts in Translating Jeremy Munday into Arabic: Asymmetric Explicitation. Across Languages and Cultures Vol. 15. No. 1. 51-66. https://doi. org/10.1556/acr.15.2014.1.3

Jiménez-Crespo, M. A. 2018. Combining Corpus and Experimental Studies: Insights into the Reception of Translated Medical Texts. The Journal of Specialized Translation No. 28. 2-22. (2018 július).

Jooken, L., Rooryck, G. 2011. The Freedom of Expressing One's Ideas: Translating La Mettrie. The Translator Vol. 17. No. 2. 233-254. https://doi.org/10.1080/13556509.20 11.10799488

Hamdan, J. M., Natour, Y. S. 2014. Gender of Cited Authors: A Problem for the EnglishArabic Translation of Scholarly Research. Babel Vol. 60. No. 3. 265-280. https://doi. org/10.1075/babel.60.3.01ham

Kaplan, R. B. 1966. Cultural Thought Patterns in Intercultural Education. Language Learning Vol. 16. 1-20. https://doi.org/10.1111/j.1467-1770.1966.tb00804.x

Kastberg, P. 2007. Cultural Issues Facing the Technical Translator. The Journal of Specialized Translation No. 8. 104-109. (2007 július).

Károly K. 2007. Szövegtan és forditás. Budapest: Akadémiai Kiadó.

Károly K. 2008. Genre Transfer Strategies and Genre Transfer Competence in Translation. Sprachtheorie und germanistische Linguistik Vol. 18. No. 1. 37-53.

Károly K. 2019. Tudományfordításról fordítástudományi megközelítésben. Fordítástudomány Vol. 21. No. 2. 5-16. https://doi.org/10.35924/fordtud.21.2.1

Kemppanen, H. 2004. Keywords and Ideology in Translated History Texts: A Corpusbased Analysis. Across Languages and Cultures Vol. 5. No. 1. 89-106. https://doi. org/10.1556/Acr.5.2004.1.5

Krein-Khüle, M. 2011. Register Shifts in Scientific and Technical Translation. A Corpusin-context Study. The Translator Vol. 17. No. 2. 391-414. https://doi.org/10.1080/135 56509.2011.10799495 
Krüger, R. 2016. The Textual Degree of Technicality as a Potential Factor Influencing the Occurrence of Explicitation in Scientific and Technical translation. The Journal of Specialized Translation No. 26. 96-115. (2016 július).

Lakoff, G., Johnson, M. 1980. Metaphors We Live By. Chicago: The University of Chicago Press.

López-Arroyo, B., Méndez-Cendón, B. 2007. Describing Phraseological Devices in Medical Abstracts: An English/Spanish Contrastive Analysis. Meta Vol. 52. No. 3. 503516. https://doi.org/10.7202/016735ar

López-Arroyo, B., Roberts, R. P. 2017. Genre and Register in Comparable Corpora: An English/Spanish Contrastive Analysis. Meta Vol. 62. No. 1. 115-136. https://doi. org/10.7202/1040469ar

López-Rodríguez, C. I., Tercedor-Sánchez, M. I. 2008. Corpora and Students' Autonomy in Scientific and Technical Translation training. The Journal of Specialized Translation No. 9. 2-19. (2008 január).

Mauranen, A. 1993. Contrastive ESP Rhetoric: Metatext in Finnish-English Economics Texts. English for Specific Purposes Vol. 12. No. 3. 3-22. https://doi.org/10.1016/08894906(93)90024-I

Mayoral-Asensio, R. (2003/2014). Translating Official Documents. Manchester: St. Jerome. Mány D. 2019. Az orvosi eufemizmusokról angolról magyarra fordított betegtájékoztatók tükrében. Fordítástudomány Vol. 21. No. 1. 76-88.

Meade, R. 2011. Translation of a Discipline. The Fate of Rankine's Engineering Science in Early Meiji-era Japan. The Translator Vol. 17. No. 2. 211-232. http://dx.doi.org/10 $.1080 / 13556509.2011 .10799487$

Méndez-Cendón, B. 2009. Combinatorial Patterns in Medical Case Reports: An EnglishSpanish Contrastive Analysis. The Journal of Specialized Translation No. 11. 169190. (2009 január).

Mendiluce-Cabrera, G., Bermúdez-Bausela, M. 2006. Sci-tech Communication: Is there a Process of Internationalization in English and Spanish? Meta Vol. 51. No. 3. 445 458. https://id.erudit.org/iderudit/013552ar

Montgomery, S. L. 2000. Science in Translation. Movements of Knowledge through Cultures and Time. Chicago, London: The University of Chicago Press.

Muňoz-Miquel, A. 2018. Differences Between Linguists and Subject-matter Experts in the Medical Translation Practice. An Empirical Descriptive Study with Professional Translators. Target Vol. 30. No. 1. 24-52. https://doi.org/10.1075/target.14130.mun

Nasser, L. A. 2014. The Translation of English Scientific Metaphorical Expressions into Arabic. Adab Al-Rafidayn Vol. 70. 25-42.

Neubert, A., Shreve, G. M. 1992. Translation as Text. Kent: The Kent State University Press.

Nord, Ch. 1997. Translating as a Purposeful Activity - Functionalist Approaches Explained. Manchester: St. Jerome. https://doi.org/10.4324/9781351189354

Olohan, M., Salama-Carr, M. 2011. Translating Science. The Translator Vol. 17. No. 2. 179-188. https://doi.org/10.1080/13556509.2011.10799485

Pietrzak, P. 2015. Stylistic Aspects of English and Polish Medical Records. Implications for Translation. The Journal of Specialized Translation Vol. 23. (2015 január).

Pilegaard, M. 1997. Translation of Medical Research Articles. In: Trosborg, A. (ed.) Text Typology and Translation. Amsterdam, Philadelphia: John Benjamins. 159-184. 
Pisanski Peterlin, A. 2005. Text-organising Metatext in Research Articles: An EnglishSlovene Contrastive Analysis. English for Specific Purposes Vol. 25. 307-319. https:// doi.org/10.1016/j.esp.2004.11.001

Pisanski Peterlin, A. 2008a. Translating Metadiscourse in Research Articles. Across Languages and Cultures Vol. 9. No. 2. 205-218. https://doi.org/10.1556/Acr.9.2008.2.3

Pisanski Peterlin, A. 2008b. The Thesis Statement in Translations of Academic Discourse: An Exploratory Study. The Journal of Specialised Translation No. 10. 10-22. (2008 július).

Pisanski Peterlin, A. 2014. Academic Discourse in Translation: Trainee Translators' Performance, Experience and Perception of Rhetorical Conventions. English for Specific Purposes Vol. 36. No. 1. 60-73. https://doi.org/10.1016/j.esp.2014.06.001

Reiss, K., Vermeer, H. J. 1984. Grundlegung einer allgemeinen Translationstheorie. Tübingen: Niemeyer.

Rogers, M. (guest ed.). 2012. Special Issue of JosTrans Terminology, Phraseology and Translation. The Journal of Specialized Translation No. 18. 1-232. (2012 július).

Sánchez, D. 2011. Translating Science: Contexts and Contests. On the Translation of a Misogynist Scientific Treatise in Early Twentieth-century Spain. The Translator Vol. 17. No. 2. 325-348. https://doi.org/10.1080/13556509.2011.10799492

Schäffner, Ch., Adab, B. 2001. The Idea of the Hybrid Text in Translation: Contact as Conflict. Across Languages and Cultures Vol. 2. No. 2. 167-180. https://akjournals.com/ view/journals/084/2/2/article-p167.xml

Sharkas, H. 2011. The Use of Glossing in Modern Original Scientific Eriting in Arabic. An Influence of Translation? The Translator Vol. 17. No. 2. 369-390. https://doi.org/ 10.1080/13556509.2011.10799494

Stolze, R. 2003. Vagueness in Economic Texts as a Translation Problem. Across Languages and Cultures Vol. 4. No. 2. 187-203. https://doi.org/10.1556/Acr.4.2003.2.2

Swales, J. M. 1990. Genre Analysis. English Academic and Research Settings. Cambridge: Cambridge University Press.

Tack Erten, S. 2012. Establishing Norms for Functional Translations from Portuguese to English: The Case of Academic Calls for Papers. The Journal of Specialized Translation No. 17. 207-223. (2012 január).

Tirkkonen-Condit, S. 2001. EU project Proposals as Hybrid Texts: Observations from a Finnish Research Project. Across Languages and Cultures Vol. 2. No. 2. 261-264. https://doi.org/10.1556/Acr.2.2001.2.9

Vandepitte, S., Vandenbussche, L., Algoet, B. 2011. Travelling Certainties. Darwin's Doubts and Their Dutch Translations. The Translator Vol. 17. No. 2. 275-300. https:// doi.org/10.1080/13556509.2011.10799490

Vincze K. 2004. Szövegtípusok és fordítás. Fordítástudomány 6. évf. 1. szám. 28-35.

Watt, R. K. 1993. The Challenges of Simplicity and Complexity: German-English Modes and Interrelationships. In: Wright, S. E., Wright, L. D. (eds) Scientific and Technical Translation. Amsterdam, Philadelphia: John Benjamins. 53-68. https://doi. org/10.1075/ata.vi.05wat

Williams, I. A. 2004. How to Manage Patients in English-Spanish Translation: A Targetoriented Contrastive Approach to Methods. Target Vol. 16. No. 1. 69-103. https://doi. org/10.1075/target.16.1.05wil 
Williams, I. A. 2005. Thematic Items Referring to Research and Researchers in the Discussion Section of Spanish Biomedical Articles and English-Spanish Translations. Babel Vol. 50. No. 2. 124-160. https://doi.org/10.1075/babel.51.2.02wil

Williams, I. A. 2007. A corpus-based study of the verb observer in English-Spanish translations of biomedical research articles. Target Vol. 19. No. 1. 85-103. https://doi. org/10.1075/target.19.1.06wil

Wright, S. E., Wright, L. D. (eds) 1993. Scientific and Technical Translation. Amsterdam, Philadelphia: John Benjamins. https://doi.org/10.1075/ata.vi

Xiangtao, F. 2007. Scientific Translation and Its Social Functions: A Descriptive-functional Approach to Scientific Textbook Translation in China. The Journal of Specialized Translation No. 7. 42-73. (2007 január). 